\title{
A psicologia e seu impacto na modernização urbana da cidade de Natal
}

\section{The psychology and its impact on urban modernization of the city of Natal}

\section{Valéria Nhome Meireles Marinho*}

Universidade Federal de Minas Gerais - UFMG, Belo Horizonte, Minas Gerais, Brasil

CARVALHO, D. de. A cidade e a alma reinventadas: a história da psicologia como signo e vetor da modernização urbana. 1.ed. São Paulo: Casa do Psicólogo, 2010.

A cidade e a alma reinventadas: a história da psicologia como signo e vetor da modernização urbana é um livro que apresenta o enraizamento da psicologia em outros campos do saber como a educação, a medicina, o direito, o serviço social e o pensamento religioso. A publicação de Denis Barros de Carvalho vem nos ajudar a compreender tais relações através de um relato histórico, resultado de sua tese de Doutorado, sobre o desenvolvimento da psicologia enquanto discurso acadêmico e prática profissional em Natal, no estado do Rio Grande do Norte.

Dividido em dois capítulos, o autor inicia a narração dos fatos históricos com a apresentação das transformações de uma cidade colonial, em processo de mudança, para uma sociedade moderna entre 1889 e 1930, vinculando a psicologia ao contexto da urbanização. Destaca o ano de 1901, quando o espaço urbano é criado e estruturado pela Resolução Municipal $n^{\circ} 15$ que marca o início da ação do Estado na área da construção. E assim, sucessivamente, observou-se uma preocupação, por parte dos governantes, para que transformações significativas ocorressem na infra-estrutura desta cidade.

No segundo capítulo, o autor analisa o fortalecimento da psicologia junto ao processo de modernização da cidade de Natal a partir da sucessão de datas e fatos. Pontua que o ambiente cultural dos indivíduos daquela cidade havia mudado, pois leituras sobre filosofia, religião, arte, literatura e ciências traziam novas ideias e questionamentos para os habitantes. Afirma, então, que a imprensa passou a exercer uma importante função tanto para a reorganização do espaço público quanto para a divulgação de ideias psicológicas. Ao 
final da década de 1920, alguns artigos sobre a psicanálise apareceram no jornal "A República" e outros foram divulgados com a finalidade de discutir a teoria freudiana. Neste contexto, alguns autores afirmavam a relação entre feminismo e psicanálise. Destacase a figura de Cristovam Dantas, do Colégio Atheneu, que defendeu as ideias eugênicas como a solução para regenerar a raça brasileira. O autor afirma que, para Cristovam e outros intelectuais da época, o Brasil não produzia tipos eugênicos satisfatórios devido à mestiçagem. Estas ideias também influenciariam a área do Direito e, com isto, deram relevância às discussões sobre patologia social e a relação entre crime e degeneração da espécie.

Percebe-se então, que a psicologia aparece, para Carvalho, como valioso instrumento de investigação social. No dizer do próprio autor, objetivou-se "[...] estudar a psicologia como um conjunto de saberes, técnicas e práticas criadas no contexto da modernidade e difundidas pelo processo da modernização a partir de sua relação com a instância de mediação que é a cidade" (p.17). Esta intencionalidade denota toda uma lógica de investigação que busca aproximar a psicologia ao esquema complexo que é a cidade, relacionadas entre si em um contexto local, político, social, temporal. Daí depreende-se a cidade como uma organização específica que deve ser estudada nos seus diversos momentos históricos (BARROS, 2007).

Ainda no decorrer da obra, o autor destaca a influência de diversos setores nas transformações sociais. Em 1911, a Psicologia foi inserida no Colégio Atheneu com o nome de Lógica e Phisyo- psychologia. Segundo o autor, neste momento há uma dificuldade da psicologia se "[...] diferenciar de suas duas fontes: filosofia e fisiologia." Entre 1923-1925 é implantada a disciplina Psicologia Pedagógica, reafirmando-se assim a importância da construção do futuro, a partir da educação da criança e a relação da psicologia com a educação da mulher. No final da década de 1930, no currículo da Escola Normal de Natal, foram estabelecidas algumas disciplinas, dentre elas, Psicologia Geral, Infantil e Aplicada à Educação. Destaca-se, ainda, o papel relevante da Escola Doméstica na inserção do discurso psicológico, pois introduziu a psicologia experimental no laboratório de puericultura, com ênfase no desenvolvimento infantil.

A partir da proclamação da República, o saber médico ganha relevância na produção do conhecimento. Para tal, dois eventos foram marcantes: o Decreto de 1921, visando a profilaxia da sífilis e - Decreto de 1932, que definiu as práticas médicas de atenção à saúde da mulher, além da regulamentação do trabalho das parteiras. Carvalho afirma então, que estes dois movimentos marcam o início do controle dos corpos de homens e mulheres pela Medicina. Paralelamente, pode-se afirmar também que a Medicina conseguiu legitimidade para diferenciar o normal do patológico. Ressalta-se a preocupação do Estado no final da década de $30 \mathrm{em}$ gerir a vida do 
doente mental, auxiliado por uma Ciência capaz de definir o que fazer. Neste contexto, a psicologia se destaca e desmembra-se em vários conteúdos em cursos universitários e como suporte para a prática psiquiátrica e, após três décadas (1963), foi criada a disciplina de Psicologia Médica no curso de Medicina da Universidade Federal do Rio Grande do Norte.

A psicologia também esteve presente no pensamento religioso da cidade de Natal. Torna-se importante a figura de Cônego Monte, com seu ingresso no Seminário São Pedro em 1922. Ele estudou as obras de Freud e incluía as ideias deste cientista em seus artigos para explicar problemas sociais e subjetivos, através de uma perspectiva católica. Daí também a psicologia ser tomada como um vetor da modernização urbana pela visão de alguns religiosos da época.

Este tecer de ideias e associações está presente em toda a obra, pois afinal, no contexto de discussões sobre sentimentos, subjetividades, arranjos sociais, política, economia, ciências e religião, é preciso tramar eventos e fatos que mostrem as mudanças temporais e de pensamento. Por meio da obra, somos levados a refletir a psicologia como parte da cidade e vice versa, a perceber a sua vinculação com as tarefas práticas do cotidiano. Afirma-se que o desenvolvimento acadêmico do discurso psicológico na capital potiguar, desde sua inserção nas escolas secundárias natalenses até sua consolidação com a criação do Curso de Psicologia da UFRN, foi marcado pela sua vinculação com tarefas práticas, nas quais se aplicavam técnicas produzidas alhures em um desconhecido contexto local (CARVALHO, 2002).

Para o leitor, talvez fique uma lacuna quanto à ausência de diálogo entre a psicologia no contexto brasileiro e internacional para que ocorra uma compreensão mais profunda sobre o desenvolvimento e profissionalização da psicologia no país. Porém, isto não compromete a leitura da obra. Torna-se então, redundante afirmar que, para compreender parte da história cultural de uma cidade, faz-se importante estudar a história da psicologia neste contexto, assim como as possibilidades de enfrentamento dos problemas modernos propostos por esta Ciência. Chama atenção a preocupação do autor em enfatizar que a história da psicologia é também parte da história cultural e elemento importante da história das cidades modernas. Denis Barros de Carvalho, nessa busca e afirmação, instiga o leitor para um movimento de pensar a psicologia em uma abordagem interdisciplinar e em um contexto histórico-cultural brasileiro, ressaltando a psicologia como um dos vetores de impacto no cotidiano das cidades.

\section{Referências}


BARROS, J.D.A. Cidade e história. Petrópolis: Vozes, 2007.

CARVALHO, D.B.; SEIXAS, P.S.; YAMAMOTO, O.H. Modernização urbana e a consolidação da psicologia em Natal- Rio Grande do Norte. Psicologia em Estudo, Maringá, v. 7, n. 1, p. 131-141, jan./jun. 2002.

\section{Endereço para correspondência}

Valéria Nhome Meireles Marinho

Av. Antônio Carlos, 6627, Pampulha, CEP: 31270-901, BH, MG, Brasil

Endereço eletrônico: valerianhome@hotmail.com

Recebido em: 01/06/2012

Aceito para publicação em: 01/12/2012

Acompanhamento do processo editorial: Ana Maria Jacó Vilela

\section{Notas}

*Enfermeira, Mestre em Enfermagem com ênfase em Saúde Pública, Doutoranda em Educação pela Faculdade de Educação da Universidade Federal de Minas Gerais. 